\title{
PENYULUHAN DAN PELAYANAN KESEHATAN PADA TK IT BAITUL IZZAH, KOTAMADYA BENGKULU, PROVINSI BENGKULU
}

\section{EXTENTION AND HEALTH FREE SERVICE AT BAITUL IZZAH KINDERGARTEN BENGKULU CITY BENGKULU PROVINCE}

\author{
Oleh: \\ Maria Eka PY, Ichsana Pranatawati, dan Sri Yunita \\ Program Studi Pendidikan Dokter \\ Fakultas Kedokteran dan Ilmu Kesehatan Universitas Bengkulu
}

\begin{abstract}
Blood group is not only as a complement of identity card, but also is required in emergency, such as in accident where people need blood transfusion. Additionally, blood group is important to know due to the fact that there are some genetic disorders caused by blood type. Golden age of a kid is under two years old. However, stunting at a kid under five years old can cause many growth disorders, including cognitive and motor growth. Therefore, nutrition intake in food is important to be concerned in order to optimize the kid's growth. Baitul Izzah was one of Integrated Islamic (IT) kindergartens in Bengkulu City. This school had three A Classes, one Pre-School Class (PAUD), and nine B Classes in which each of them consisted of twenty five pupils and two teachers. The objective of this dedication is to know the pupils' nutritional status at the school so that parents can know their kid's growth. Besides, this dedication aims to give counseling about how to wash hands correctly in which we know that washing hands before eating or after doing activities will decrease the risk of communicable diseases like wormy disease and influenza. This activity was accomplished on August 16, 2014. It was followed by two classes at Kindergarten B which consisted of 46 pupils and accompanied by the class teacher. Based on IMT (Body Mass Index), it was found that there were 18 pupils with normal nutritional status, 19 pupils were obesity, 2 pupils were underweight and 7 pupils were overweight. From the blood group checkup, it was found that all of the pupils had rhesus + with various blood groups. Furthermore, the counseling about how to wash hands correctly and good foods was accomplished. From the counseling, it was found that the pupils of the kindergarten were very enthusiastic. Following the counseling, direct practice about washing hands correctly was also conducted as well as giving nutritional food like mung bean porridge and milk, and souvenirs to the school at the end.
\end{abstract}

Keywords: Nutritional Status, Blood Type, Washing Hands Correctly, Kindergarten

\section{PENDAHULUAN}

TK IT baitul Izzah adalah salah satu TK IT yang terdapat di Kota Bengkulu. TK ini mempunyai 13 kelas yang terdiri dari 3 kelas A, 9 kelas B, dan 1 Play group.TK ini memiliki murid dengan berbagai latar belakang sosial ekonomi. Seperti kita ketahui, 
masing-masing orang harus mengetahui golongan darahnya, karena kita tidak tahu kapan musibah terjadi, misalnya tiba-tiba membutuhkan transfusi darah. Oleh karena itu dengan mengetahui golongan darah secara dini akan mempermudah tindakan. Selain hemolisis, ada kelainan genetik lain yang juga mengancam ibu serta bayi yang dikandung. Terutama jika ibu berdarah rhesus negatif sedangkan suami berdarah rhesus positif. Masalah ini biasanya terjadi pada perkawinan antar bangsa. Mengetahui golongan darah akan mengurangi risiko berbagai penyakit.

Kegagalan pertumbuhan (stunting) pada anak usia di bawah lima tahun (balita) dapat menyebabkan berbagai gangguan perkembangan, termasuk perkembangan kognitif dan motorik. Faktor-faktor yang berhubungan signifikan dengan status gizi balita adalah tinggi badan ibu, tingkat kecukupan energi dan protein balita dan panjang badan lahir balita. Faktor-faktor yang berkaitan signifikan dengan tingkat perkembangan motorik kasar dan motorik halus balita adalah status gizi balita, lama mengikuti PAUD dan usia balita. Faktor-faktor yang berhubungan signifikan dengan tingkat perkembangan kognitif balita adalah status gizi balita, usia balita, lama mengikuti PAUD dan praktik pengasuhan balita oleh ibu. Tingkat kecukupan gizi balita, terutama energi dan protein, berhubungan dengan status gizi dan perkembangan mereka.

Definisi Mencuci tangan adalah membasuh kedua telapak tangan dengan sabun dan air mengalir sebelum dan sesudah melakukan tindakan dengan tujuan untuk menghilangkan kuman. Membiasakan mencuci tangan sejak dini merupakan langkah awal untuk mencegah masuknya kuman dan resiko tertularnya penyakit.

Kapan cuci tangan dengan sabun harus dilakukan yakni sebagai berikut :

- Sebelum Makan

- Sebelum dan sesudah mengolah makanan

- Sesudah dari kamar mandi atau WC

- Setelah kontak dengan orang yang batuk atau bersin

- Tangan terlihat kotor

- Setelah menangani orang sakit

Biasakan mencuci tangan sejak anak-anak, hal ini dikarenakan sebagai berikut :

1) Anak-anak perlu tahu cara mencuci tangan dengan benar

2) Bantuan dan contoh yang benar merupakan elemen penting dalam membentuk kebiasaan mencuci tangan pada anak-anak

3) Anak-anak akan belajar dari mencontoh, oleh karena itu biarkan mereka mencontoh dari orang-orang dewasa yang merawatnya.

Adapun 7 langkah mencuci tangan dengan sabun yaitu :

1) Mencuci tangan dibawah air mengalir dengan sabun. Gosok telapak tangan yang satu dengan telapak tangan satunya.

2) Telapak tangan kanan diatas punggung telapak tangan kiri dan jari saling menyilang.

3) Gosok telapak tangan kiri dengan telapak tangan kanan dan jari saling menyilang.

4) Punggung jari dari tangan berlawanan kiri dan kanan bergantian 
5) Putar ibu jari dalam telapak tangan yang berlawanan

6) Gosok jari di telapak tangan yang berlawanan

7) Pegang pergelangan tangan kiri dengan tangan kanan dan sebaliknya dengan gerakan memutar.

Pendidikan Kesehatan merupakan salah satu unsur utama dalam Pendidikan Anak Usia Dini. Anak usia dini merupakan masa emas untuk melandasi keberhasilan proses kehidupan untuk menjadi individu, masyarakat dan bangsa yang sehat, sejahtera, dan bermartabat. Pendidikan kesehatan anak usia dini merupakan unsur utama dalam pendidikan anak usia dini dan tidak hanya sebagai proses pembelajaran kesehatan, tetapi mengoptimalkan pertumbuhan fisik dan potensi kognitif dan emosional untuk melandasi karakter kepribadian dan kecerdasan serta landasan utama dalam pendidikan selanjutnya. Pendidikan kesehatan anak usia dini dipengaruhi oleh perkembangan pandangan sehat, paradigma pembangunan, faktor determinan kesehatan, dan pelayan kesehatan dan pendidikan kesehatan.

Ada beberapa cara melakukan penilaian status gizi pada kelompok masyarakat. Salah satunya adalah dengan pengukuran tubuh manusia yang dikenal dengan Antropometri. Dalam pemakaian untuk penilaian status gizi, antropomteri disajikan dalam bentuk indeks yang dikaitkan dengan variabel lain. Variabel tersebut adalah sebagai berikut :

\section{a. Umur}

Umur sangat memegang peranan dalam penentuan status gizi, kesalahan penentuan akan menyebabkan interpretasi status gizi yang salah (Depkes, 2004).

\section{b. Berat Badan}

Berat badan merupakan salah satu ukuran yang memberikan gambaran massa jaringan, termasuk cairan tubuh. Berat badan sangat peka terhadap perubahan yang mendadak baik karena penyakit infeksi maupun konsumsi makanan yang menurun. Berat badan ini dinyatakan dalam bentuk indeks $\mathrm{BB} / \mathrm{U}$ (Berat Badan menurut Umur) atau melakukan penilaian dengam melihat perubahan berat badan pada saat pengukuran dilakukan, yang dalam penggunaannya memberikan gambaran keadaan kini. Berat badan paling banyak digunakan karena hanya memerlukan satu pengukuran, hanya saja tergantung pada ketetapan umur, tetapi kurang dapat menggambarkan kecenderungan perubahan situasi gizi dari waktu ke waktu (Abunain, 1990).

\section{c. Tinggi Badan}

Tinggi badan memberikan gambaran fungsi pertumbuhan yang dilihat dari keadaan kurus kering dan kecil pendek. Tinggi badan sangat baik untuk melihat keadaan gizi masa lalu terutama yang berkaitan dengan keadaan berat badan lahir rendah dan kurang gizi pada masa balita. Tinggi badan dinyatakan dalam bentuk Indeks TB/U (tinggi badan menurut umur), atau juga indeks BB/TB ( Berat Badan menurut Tinggi Badan) jarang dilakukan karena perubahan tinggi badan yang lambat dan biasanya hanya dilakukan setahun sekali. (Depkes RI, 2004).Berat badan dan tinggi badan adalah 
salah satu parameter penting untuk menentukan status kesehatan manusia, khususnya yang berhubungan dengan status gizi. Penggunaan Indeks BB/U, TB/U dan BB/TB merupakan indikator status gizi untuk melihat adanya gangguan fungsi pertumbuhan dan komposisi tubuh. Penggunaan berat badan dan tinggi badan akan lebih jelas dan sensitive/peka dalam menunjukkan keadaan gizi kurang bila dibandingkan dengan penggunaan BB/U. Dinyatakan dalam BB/TB, menurut standar WHO bila prevalensi kurus/wasting $<-2 \mathrm{SD}$ diatas $10 \%$ menunjukan suatu daerah tersebut mempunyai masalah gizi yang sangat serius dan berhubungan langsung dengan angka kesakitan.

Tabel 1. Penilaian Status Gizi berdasarkan Indeks BB/U,TB/U, BB/TB Standart Baku Antropometeri WHO-NCHS

\begin{tabular}{llll}
\hline No & Indeks yang dipakai & Batas Pengelompokan & Sebutan Status Gizi \\
\hline 1 & BB/U & $<-3 \mathrm{SD}$ & Gizi buruk \\
& & $-3 \mathrm{~s} / \mathrm{d}<-2 \mathrm{SD}$ & Gizi kurang \\
& & $-2 \mathrm{~s} / \mathrm{d}+2 \mathrm{SD}$ & Gizi baik \\
& & $>+2 \mathrm{SD}$ & Gizi lebih \\
2 & $\mathrm{~TB} / \mathrm{U}$ & $<-3 \mathrm{SD}$ & Sangat Pendek \\
& & $-3 \mathrm{~s} / \mathrm{d}<-2 \mathrm{SD}$ & Pendek \\
& & $-2 \mathrm{~s} / \mathrm{d}+2 \mathrm{SD}$ & Normal \\
& & $>+2 \mathrm{SD}$ & Tinggi \\
3 & $\mathrm{BB} / \mathrm{TB}$ & $<-3 \mathrm{SD}$ & Sangat Kurus \\
& & $-3 \mathrm{~s} / \mathrm{d}<-2 \mathrm{SD}$ & Kurus \\
& & $-2 \mathrm{~s} / \mathrm{d}+2 \mathrm{SD}$ & Normal \\
& & $>+2 \mathrm{SD}$ & Gemuk
\end{tabular}

Sumber: Depkes RI 2004

Tabel 2. Interpretasi Status Gizi Berdasarkan Tiga Indeks Antropometri (BB/U,TB/U, BB/TB Standart Baku Antropometeri WHO-NCHS)

\begin{tabular}{lllll}
\hline \multirow{2}{*}{ No } & \multicolumn{3}{c}{ Indeks yang Digunakan } & \multirow{2}{*}{ Interpretasi } \\
& BB/U & TB/U & BB/TB & \\
\hline 1 & Rendah & Rendah & Normal & Normal, dulu kurang gizi \\
& Rendah & Tinggi & Rendah & Sekarang kurang ++ \\
& Rendah & Normal & Rendah & Sekarang kurang + \\
2 & Normal & Normal & Normal & Normal \\
& Normal & Tinggi & Rendah & Sekarang kurang \\
& Normal & Rendah & Tinggi & Sekarang lebih, dulu kurang \\
3 & Tinggi & Tinggi & Normal & Tinggi, normal \\
& Tinggi & Rendah & Tinggi & Obese \\
& Tinggi & Normal & Tinggi & Sekarang lebih, belum obese \\
\hline
\end{tabular}

Keterangan : untuk ketiga indeks ( BB/U,TB/U, BB/TB) :

Rendah : $<-2$ SD Standar Baku Antropometri WHO-NCHS

Normal : $-2 \mathrm{~s} / \mathrm{d}+2$ SD Standar Baku Antropometri WHO-NCHS

Tinggi : > + 2 SD Standar Baku Antropometri WHO-NCHS 
Data baku WHO-NCHS indeks BB/U, TB/U dan BB/TB disajikan dalan dua versi yakni persentil (persentile) dan skor simpang baku (standar deviation score $=\mathrm{z}$ ). Menurut Waterlow, et al, dalam Abunain (1990) gizi anak-anak di negara-negara yang populasinya relatif baik (well-nourished), sebaiknya digunakan "presentil”, sedangkan di negara untuk anak-anak yang populasinya relatif kurang (under-nourished) lebih baik menggunakan skor simpang baku (SSB) sebagai persen terhadap median baku rujukan (Abunain,1990).

Pengukuran Skor Simpang Baku (Z-score) dapat diperoleh dengan mengurangi Nilai Induvidual Subjek (NIS) dengan Nilai Median Baku Rujukan (NMBR) pada umur yang bersangkutan, hasilnya dibagi dengan Nilai Simpang Baku Rujukan (NSBR). Atau dengan menggunakan rumus :

\section{Z-score $=($ NIS-NMBR $) /$ NSBR}

Status gizi berdasarkan rujukan WHO-NCHS dan kesepakatan Cipanas 2000 oleh para pakar Gizi dikategorikan seperti diperlihatkan pada Tabel 1 diatas serta di interpretasikan berdasarkan gabungan tiga indeks antropometri seperti yang terlihat pada Tabel 2.

Untuk memperjelas penggunaan rumur Zskor dapat dicontohkan sebagai berikut :

Diketahui $\mathrm{BB}=60 \mathrm{~kg}, \mathrm{~TB}=145 \mathrm{~cm}$, Umur : karena umur dengan indeks BB/U, TB/U dan $\mathrm{BB} / \mathrm{TB}$ berdasarkan WHO-NCHS hanya dibatasi $<18$ tahun maka disini dicontohkan anak laki-laki usia 15 tahun.

Tabel 3. Table weight $(\mathrm{kg})$ by age of boys aged 15 year from WHO-NCHS

\begin{tabular}{ccccccccc}
\hline \multicolumn{2}{c}{ Age } & \multicolumn{7}{c}{ Standard Deviations } \\
\hline Yr & Mth & -3 sd & -2 sd & -1 sd & Median & $+1 \mathrm{sd}$ & $+2 \mathrm{sd}$ & $+3 \mathrm{sd}$ \\
\hline 15 & 0 & 31.6 & 39.9 & 48.3 & 56.7 & 69.2 & 81.6 & 94.1 \\
\hline
\end{tabular}

Sumber: WHO, Measuring Change an Nutritional Status, Genewa 1985

Tabel 4. Table weight $(\mathrm{kg})$ by stature of boys $145 \mathrm{~cm}$ in Height from WHO-NCHS

\begin{tabular}{|c|c|c|c|c|c|c|c|}
\hline \multirow{2}{*}{$\begin{array}{c}\text { Stature } \\
\mathrm{Cm}\end{array}$} & \multicolumn{7}{|c|}{ Standard Deviations } \\
\hline & $-3 \mathrm{sd}$ & $-2 \mathrm{sd}$ & $-1 \mathrm{sd}$ & Median & $+1 \mathrm{sd}$ & $+2 \mathrm{sd}$ & $+3 \mathrm{sd}$ \\
\hline 145 & 24.8 & 28.8 & 32.8 & 36.9 & 43.0 & 49.2 & 55.4 \\
\hline
\end{tabular}

Sumber: WHO, Measuring Change an Nutritional Status, Genewa 1985

Tabel 5. Table stature (cm) by age of boys aged 15 year from WHO-NCHS

\begin{tabular}{ccccccccc}
\hline \multicolumn{2}{c}{ Stature } & \multicolumn{7}{c}{ Standard Deviations } \\
\hline $\mathrm{Yr}$ & Mth & $-3 \mathrm{sd}$ & $-2 \mathrm{sd}$ & $-1 \mathrm{sd}$ & Median & $+1 \mathrm{sd}$ & $+2 \mathrm{sd}$ & $+3 \mathrm{sd}$ \\
\hline 15 & 0 & 144.8 & 152.9 & 160.9 & 169.0 & 177.1 & 185.1 & 193.2 \\
\hline
\end{tabular}

Sumber: WHO, Measuring Change an Nutritional Status, Genewa 1985

Jadi untuk indeks BB/U adalah :

$=\mathrm{Z}$ Score $=(60 \mathrm{~kg}-56,7) / 8.3=+0,4 \mathrm{SD}$

$=$ status gizi baik 
Untuk IndeksTB/U adalah :

$=\mathrm{Z}$ Score $=(145 \mathrm{~kg}-169) / 8.1=-3.0 \mathrm{SD}$

$=$ status gizi pendek

Untuk Indeks BB/TB adalah :

$=\mathrm{Z}$ Score $=(60-36.9) / 4=+5.8 \mathrm{SD}$

$=$ status gizi gemuk

\section{Definisi Operasional Status Gizi}

Sebenarnya untuk mendefinisikan operasional status gizi ini dapat dilakukan di klinik kesehatan swasta maupun pemerintah yang menyediakan pengukuran status gizi, namun demikian yang perlu diketahui masyarakat adalah pengertian dan pemahaman dari status gizi anak, selanjutnya ketika mengunjungi klinik gizi hasilnya dapat segera diketahui termasuk upaya-upaya mempertahankan status gizi yang baik.

Status Gizi Anak adalah keadaan kesehatan anak yang ditentukan oleh derajat kebutuhan fisik energi dan zat-zat gizi lain yang diperoleh dari pangan dan makanan yang dampak fisiknya diukur secara antroppometri (Suharjo, 1996), dan dikategorikan berdasarkan standar baku WHO-NCHS dengan indeks BB/U, TB/U dan BB/TB.

Indikasi pengukuran dari variabel ini ditentukan oleh :

a. Penimbangan Berat Badan (BB) dan pengukuran Tinggi Badan (TB) Dilakukan oleh petugas klinik gizi sesuai dengan syarat-syarat penimbangan berat badan dan pengukuran tinggi badan yang baik dan benar penggunaan timbangan berat badan dan meteran tinggi badan (mikrotoise).

b. Penentuan umur anak ditentukan sesuai tanggal penimbangan BB dan Pengukuran TB, kemudian dikurangi dengan tanggal kelahiran yang diambil dari data identitas anak pada sekolah masing-masing, dengan ketentuan 1 bulan adalah 30 hari dan 1 tahun adalah 12 bulan.

Kriteria objektifnya dinyatakan dalam rata-rata dan jumlah $\mathrm{Z}$ score simpang baku (SSB) induvidu dan kelompok sebagai presen terhadap median baku rujukan (Waterlow.et al, dalam Abunain, 1990) Untuk menghitung SSB dapat dipakai rumus :

$$
\text { Skor Baku Rujukan }=\frac{N I S-N M B R}{N S B R}
$$

Dimana :

NIS : Nilai Induvidual Subjek

NMBR : Nilai Median Baku Rujukan

NSBR : Nilai Simpang Baku Rujukan

Hasil pengukuran dikategorikan sbb

a) Untuk $\mathrm{BB} / \mathrm{U}$

1. Gizi Kurang Bila SSB $<-2$ SD

2. Gizi Baik Bila SSB $-2 \mathrm{~s} / \mathrm{d}+2 \mathrm{SD}$

3. Gizi Lebih Bila SSB $>+2 \mathrm{SD}$ 
b) $\mathrm{TB} / \mathrm{U}$
1. Pendek
Bila SSB $<-2$ SD
2. Normal
Bila SSB $-2 \mathrm{~s} / \mathrm{d}+2 \mathrm{SD}$
3. Tinggi
Bila SBB > $>2$ SD

c) $\mathrm{BB} / \mathrm{TB}$
1. Kurus
Bila SSB $<-2 \mathrm{SD}$
2. Normal
Bila SSB $-2 \mathrm{~s} / \mathrm{d}+2 \mathrm{SD}$
3. Gemuk
Bila SSB $>+2$ SD

Dan juga status gizi diinterpretasikan berdasarkan tiga indeks antropomteri, (Depkes, 2004), dan dikategorikan seperti yang ditunjukan pada Tabel 6.

Tabel 6. Kategori Interpretasi Status Gizi Berdasarkan Tiga Indeks (BB/U,TB/U, BB/TB Standart Baku Antropometeri WHO-NCHS)

\begin{tabular}{|c|c|c|c|}
\hline \multirow{2}{*}{ Interpretasi } & \multicolumn{3}{|c|}{ Indeks yang digunakan } \\
\hline & $\mathrm{BB} / \mathrm{U}$ & $\mathrm{TB} / \mathrm{U}$ & $\mathrm{BB} / \mathrm{TB}$ \\
\hline Normal, dulu kurang gizi & Rendah & Rendah & Normal \\
\hline Sekarang kurang ++ & Rendah & Tinggi & Rendah \\
\hline Sekarang kurang + & Rendah & Normal & Rendah \\
\hline Normal & Normal & Normal & Normal \\
\hline Sekarang kurang & Normal & Tinggi & Rendah \\
\hline Sekarang lebih, dulu kurang & Normal & Rendah & Tinggi \\
\hline Tinggi, normal & Tinggi & Tinggi & Normal \\
\hline Obese & Tinggi & Rendah & Tinggi \\
\hline Sekarang lebih, belum obese & Tinggi & Normal & Tinggi \\
\hline
\end{tabular}

Keterangan : untuk ketiga indeks ( $\mathrm{BB} / \mathrm{U}, \mathrm{TB} / \mathrm{U}, \mathrm{BB} / \mathrm{TB})$ :

Rendah : $<-2$ SD Standar Baku Antropometri WHO-NCHS

Normal : -2 s/d +2 SD Standar Baku Antropometri WHO-NCHS

Tinggi : $>+2$ SD Standar Baku Antropometri WHO-NCHS

Sumber: Depkes RI 2004

PAUD Baitul Izzah Kota Bengkulu merupakan salah satu PAUD/TK yang memiliki jumlah murid 350 orang, dari berbagai latar belakang keluarga, ekonomi, tempat tinggal, pola pengasuhan orang tua, pola makan, dan tingkat kebersihan, maka perlu diketahui bagaimana status gizi dari anak-anak PAUD/TK serta tingkat pengetahuan dini muridmurid mengenai gizi yang baik, kebersihan tangan dan golongan darah perlu di ketahui bersama.

Kegiatan ini bertujuan untuk mengetahui jenis golongan darah dan status gizi yang dimiliki oleh anak PAUD Baitul izzah serta memberikan pengetahuan dan mengajarkan anak-anak PAUD Baitul Izzah bagaimana cara mencuci tangan yang baik dan benar serta penyuluhan tentang makanan yang sehat dan bergizi.

Dari kegiatan ini para siswa diharapkan :

1. Orang tua dapat mengetahui jenis golongan darah yang dimiliki oleh anak 
2. Dari penyuluhan diharapakan orang tua dan anak dapat mengetahui makanan apa yang baik untuk kesehatannya.

3. Orang tua bisa mengetahui keadaan gizi anak

4. Diharapkan anak memiliki kebiasaan mencuci tangan sebelum makan

5. Diharapkan anak dapat melakukan mencuci tangan dengan baik setelah makan

6. Diharapkan anak dapat mengetahui bahaya dan penayakit apa yang bisa terjadi jika tidak cuci tangan sebelum makan.

\section{METODE PENGABDIAN}

Metode kegiatan yang digunakan adalah Penyuluhan kesehatan yang dilakukan dengan cara menyebarkan pesan, menanamkan keyakinan, sehingga masyarakat tidak saja sadar, tahu dan mengerti, tetapi juga mau dan bisa melakukan suatu anjuran yang ada hubungannya dengan kesehatan. Penyuluhan kesehatan adalah gabungan berbagai kegiatan dan kesempatan yang berlandaskan prinsip-prinsip belajar untuk mencapai suatu keadaan, dimana individu, keluarga, kelompok atau masyarakat secara keseluruhan ingin hidup sehat, tahu bagaimana caranya dan melakukan apa yang bisa dilakukan, secara perseorangan maupun secara kelompok dan meminta pertolongan. Kegitan ini meliputi :

1. Pemeriksaan golongan darah murid-murid TK

2. Penyuluhan status gizi yang baik dengan cara mengukur berat badan, tinggi badan

3. Praktek mencuci tangan yang baik dan benar

4. Pemberian makanan sehat

5. Melakukan tanya jawab serta diskusi dengan para siswa siswa dan guru

6. Pemberian kenang-kenangan kepada pihak sekolah.

\section{HASIL DAN PEMBAHASAN}

Kegiatan ini berlangsung dengan lancar, dengan beberapa tahapan meliputi :

1. Pemeriksaan golongan darah murid-murid TK

2. Penyuluhan status gizi yang baik dengan cara mengukur berat badan, tinggi badan

3. Praktek mencuci tangan yang baik dan benar

4. Pemberian makanan sehat

5. Melakukan tanya jawab serta diskusi dengan para siswa siswa dan guru

Dengan rincian kegiatan sebagai berikut :

- Tahap persiapan dilaksanakan pada pukul $07.00 \mathrm{~s} / \mathrm{d} 08.00 \mathrm{WIB}$, persiapan meliputi peralatan-peralatan yang telah disiapkan seperti alat medis cek golongan darah, peralatan presentasi di depan kelas.

- Tahap Pelaksanaan dilaksankan pada pukul $08.00 \mathrm{~s} / \mathrm{d} 12.00 \mathrm{WIB}$, pertama-tama tim melakukan sosialisasi dan penyuluhan mengenai cara cuci tangan yang baik dan benar 
dimana anak-anak TK diajarkan langsung dan diberi contoh langsung cara mencuci tangan. Selanjutnya presentasi mengenai gizi yang baik, anak-anak TK di berikan pemahaman dan contoh makanan yang baik untuk dikonsumsi sehari-hari dalam rangka pemenuhan status gizi yang baik dan tubuh yang sehat. Acara dimeriahkan dengan membagikan susu UHTdan Jus kacang hijau dengan tujuan untuk memberikan edukasi kepada anak-anak mengenai makanan sehat dan bergizi.

- Dari kegiatan ini, meliputi beberapa kegiatan, yang pertama berupa penyuluhan. Anakanak begitu antusias dalam mengikuti penyuluhan. Ini terbukti dari pertanyaan yang diajuakan oleh narasumber dapat terjawab dengan baik

- Kegiatan yang tidak kalah pentingnya yaitu dilanjutkan dengan tes/pemeriksaan golongan darah dan pengukuran tinggi, berat badan. Kegiatan ini diikuti oleh 38 orang anak-anak TK dengan bermacam-macam respon seperti malu-malu, antusias bahkan ada juga yang takut namun berkat cara pendekatan dan edukasi, anak-anak TK bersedia mengikuti pemeriksaan golongan darah dan pengukuran tinggi, serta berat badan.

Berikut hasil pengukuran berat badan dan tinggi badan. Dari hasil pengukuran tersebut diperoleh :

Jumlah murid dengan IMT normal $\quad: 18$ orang

Jumlah murid dengan IMT tidak normal/underweight $\quad: 2$ orang

Jumlah murid dengan IMT tidak normal/overweight $\quad: 7$ orang

Jumlah murid dengan IMT kegemukan/obese : : :19 orang 
Tabel 7. Hasil pengukuran berat badan dan tinggi badan

\begin{tabular}{|c|c|c|c|c|}
\hline Nama & TB (cm) & BB (kg) & IMT & KET \\
\hline Abrar Hanif Sanitra & 100 & 16 & 16 & Normal \\
\hline Athalia Sabrina Zahra & 95 & 14 & 15,512465 & Normal \\
\hline Fachri Buana Pratama & 98 & 15 & 15,618492 & Normal \\
\hline Farah Dzakiyah Sanuar & 108 & 24 & 20,576132 & Obese \\
\hline Farhatul Muhaiyah & 96 & 13 & 14,105903 & Normal \\
\hline Hapza Wielya Wasil & 102 & 17 & 16,339869 & Overweight \\
\hline Khanza Flaviana Carissa & 98 & 13 & 13,536027 & Underweight \\
\hline Khozin Darel Hermawan & 102 & 16 & 15,3787 & Normal \\
\hline Muhammad Akhtar Maryadi & 107 & 18 & 15,721897 & Overweight \\
\hline Muhammad Altaf Nabil & 100 & 13 & 13 & Underweight \\
\hline Muhammad Andika Nur Hidayat & 105 & 20 & 18,14059 & Obese \\
\hline Muhammad Hisyam Al-Ashadjais & 110 & 22 & 18,181818 & Obese \\
\hline Muhammad Reynaldo Ragil & 112 & 21 & 16,741071 & Obese \\
\hline Muhammad Rifqi Aditya Purwanto & 108 & 17 & 14,57476 & Overweight \\
\hline Muhammad Sultan Akbar & 112 & 20 & 15,943878 & Obese \\
\hline Nafilah Syakira & 100 & 15 & 15 & Normal \\
\hline Nursyafitri Dwijaya & 107 & 28 & 24,456284 & Obese \\
\hline Raissa Adrienne Suharto & 105 & 22 & 19,954649 & Obese \\
\hline Rameyza Abinaya & 102 & 17 & 16,339869 & Normal \\
\hline Ranidyah Sabrina & 114 & 20 & 15,389351 & Obese \\
\hline Taleisha Aulia Islami & 106 & 15 & 13,349947 & Normal \\
\hline Taqiv Erfan & 98 & 16 & 16,659725 & Normal \\
\hline Zaki Ra'id Nashshar & 110 & 20 & 16,528926 & Obese \\
\hline Aisyah Isni Amalia & 103 & 19 & 17,909322 & Obese \\
\hline Alifatul Akram & 102 & 15 & 14,417532 & Normal \\
\hline Aliyah Khairawi S. & 100 & 18 & 18 & Overweight \\
\hline Amanda Fahnika & 107 & 20 & 17,468775 & Obese \\
\hline Chika Zania Salsabila & 93 & 15 & 17,343045 & Normal \\
\hline Farel Zayyan Abdilla & 111 & 20 & 16,232449 & Obese \\
\hline Fadhil Rizqi Gunawan & 102 & 16 & 15,3787 & Normal \\
\hline Kevin Abdul Aziz & 110 & 20 & 16,528926 & Obese \\
\hline Khanza Dahayu Nazifa & 92 & 14 & 16,540643 & Normal \\
\hline Kafka Aliturrahman & 107 & 18 & 15,721897 & Overweight \\
\hline Ezio Azzura Xahega & 116 & 20 & 14,863258 & Obese \\
\hline M. Asyrofun Ni'am & 108 & 20 & 17,146776 & Obese \\
\hline Mulya Hangi Alehian & 106 & 16 & 14,239943 & Normal \\
\hline Nadirah Jaeni Ramadhan & 100 & 15 & 15 & Normal \\
\hline Putri Taqiyyah Khansa & 102 & 22 & 21,145713 & Obese \\
\hline Qatrunnanda Filia F. & 103 & 24 & 22,622302 & Obese \\
\hline Rifqi Habibullah & 104 & 18 & 16,642012 & Overweight \\
\hline Rahmat Rian Hanafi & 101 & 17 & 16,665033 & Normal \\
\hline Syifa Ivana Queni A. & 104 & 17 & 15,717456 & Normal \\
\hline Thirzza Artika Putri & 103 & 18 & 16,966726 & Overweight \\
\hline Tiara Veyporosy Nanda L. & 100 & 14 & 14 & Normal \\
\hline Vanya Keysa Kesani & 107 & 23 & 20,089091 & Obese \\
\hline Zeeba Farras Kalila & 110 & 20 & 16,528926 & Obese \\
\hline
\end{tabular}

Sumber: Hasil Pemeriksaan 
Hasil pemeriksaan golongan darah sebagai berikut.

Tabel 8. Hasil pemeriksaan golongan darah

\begin{tabular}{lcclcc}
\hline \multicolumn{1}{c}{ Nama } & $\begin{array}{c}\text { Golongan } \\
\text { Darah }\end{array}$ & Rhesus & Nama & $\begin{array}{c}\text { Golongan } \\
\text { Darah }\end{array}$ & Rhesus \\
\hline Abrar & $\mathrm{A}$ & + & Deki & $\mathrm{O}$ & + \\
Fahri & $\mathrm{O}$ & + & Intan & $\mathrm{A}$ & + \\
Hisyam & $\mathrm{O}$ & + & Atan & $\mathrm{O}$ & + \\
Sultan & $\mathrm{A}$ & + & Ayu & $\mathrm{O}$ & + \\
Aliya & $\mathrm{O}$ & + & Dea & $\mathrm{O}$ & + \\
Kanza & $\mathrm{A}$ & + & Khalila & $\mathrm{AB}$ & + \\
Fala & $\mathrm{AB}$ & + & Ebe & $\mathrm{A}$ & + \\
Tiara & $\mathrm{AB}$ & + & Aisyah & $\mathrm{A}$ & + \\
Zahra & $\mathrm{A}$ & + & Azam & $\mathrm{A}$ & + \\
Nabil & $\mathrm{A}$ & + & Khozi & $\mathrm{O}$ & + \\
Khaira & $\mathrm{O}$ & + & Zahra & $\mathrm{B}$ & + \\
Nabila & $\mathrm{B}$ & + & Listi & $\mathrm{B}$ & + \\
Bagas & $\mathrm{O}$ & + & Neneng & $\mathrm{O}$ & + \\
Arif & $\mathrm{A}$ & + & Leni & $\mathrm{O}$ & + \\
Roziq & $\mathrm{A}$ & + & Sulis & $\mathrm{A}$ & + \\
Rizki & $\mathrm{O}$ & + & Yanti & $\mathrm{AB}$ & + \\
Rahma & $\mathrm{O}$ & + & Ulfa & $\mathrm{B}$ & + \\
Fathan & $\mathrm{B}$ & + & Eka & $\mathrm{O}$ & + \\
Hariz & $\mathrm{O}$ & + & Neni & $\mathrm{A}$ & + \\
\hline
\end{tabular}

Sumber: Hasil Pemeriksaan

\section{KESIMPULAN DAN SARAN}

\section{Kesimpulan}

Berdasarkan hasil diatas dapat diketahui bahwa status gizi anak TK IT Baitul Izzah sudah cukup baik, bahkan banyak yang mengalami obesitas. Sebagian besar anak bergolongan darah "O" dengan Rhesus (+).

\section{Saran}

Hal ini juga bisa menjadi bahan masukan bagi orang tua siswa agar lebih memperhatikan asupan gizi bagi anaknya. 


\section{DAFTAR PUSTAKA}

Abunain, Djumadias, 1990, Aplikasi Antropometri sebagai Alat Ukur Status Gizi, Puslitbang Gizi, Bogor.

Depkes, RI., 2004, Analisis Situasi Gizi dan Kesehatan Masyarakat, Jakarta. Suharjo, 1996, Gizi dan Pangan, Kanisius, Yogyakarta.

WHO, 1985, Measuring Change in Nutritional Status, Genewa. 